DOI: 10.20472/BMC.2017.005.013

SONALI SAHA

MIT School of Telecom Management, India

\title{
“A DESCRIPTIVE STUDY OF UNDERSTANDING TALENT MANAGEMENT PRACTICES FOR MANAGING TODAY'S GLOBAL WORKFORCE AND IN
}

\begin{abstract}
:
This study is intended to understand the significance and benefits of Talent Management Practices and the extent of its application in Large Scale IT companies.

This paper commences with exploring the concept of Talent Management and its various dimensions, existing Talent Management Practices in IT Industries, how Talent Management process Aligned to Business Goals and how Talent can lead to increase the business competitiveness. The study further analyze the the process of talent assessment and tracking in the organization.

The role of researcher here intends to identify the various key drivers for Talent Management and to find out the Financial benefits of Talent Management.This research paper indicates a starting point for organisations to develop a "talent mindset", to ensure there is an agreed and understood definition of Talent/ Talent Management and why it is an important focus for the business.

Since its conception, a number of researches have been carried out on Talent Management, most of them in United States of America. A visible research gap exists in the area of identification and measurement of drivers for Talent Management and its impact on business. This points out the relative importance of this concept and hence the need for research on the same in the Indian context as well.
\end{abstract}

\section{Keywords:}

Talent Management, Key Drivers, Business Competitiveness

JEL Classification: 124 


\section{Background of the study}

\section{This section explores the concept of Talent Management and its various dimensions}

\subsection{What is Talent Management?}

In the broadest sense, Talent Management has been described as "a deliberate and ongoing process that systematically identifies, assesses, develops and retains talent to meet current and future business needs and objectives." Talent Management begins as soon as recruiters identify potential hires and continues throughout a person's tenure as an employee of the hiring organization.

\subsection{The Need of Talent Management}

William J. Rothwell, in his article "Replacement planning: a starting point for succession planning and Talent Management", International Journal of Training and Development 15:1 ISSN 1360-3736 says, despite growing interest, however, some organizations are ill-prepared emergency succession of the CEO (Anon., 2009). That is all the more troubling because, according to some experts, the cost of replacing a key person can be as much as 24 times the person's annual salary (Miller, 2005).

\subsection{Why do employers need to develop a Talent Management strategy?}

First, talent and leadership continue to be scarce. Fewer qualified workers and leaders are entering the workforce to replace aging workers and leaders who are leaving to retire.

Secondly, Talent of the 20th century need to be rethought to keep pace with the reality of a rapidly changing 21 st century business environment.

\subsection{Is Talent Management an objective or a journey?}

Much like a company's commitment to provide world-class service to its clients, effective Talent Management is far more than a business goal or objective with a beginning, middle, and end.

\subsection{Current Researches on Talent Management}

According to Wikipedia, the free encyclopedia, Talent Management as a process emerged in the 1900s and continues to be adopted, as more companies come to realize that their employees' talent and skills drive their business success.

Darin Phillips, "Financial Value of Talent Management", 2002, observes that companies that want to grow and improve their systems and processes must focus on the people practices that allow or foster that growth and improvement. Talent Management is no longer a cutting -edge field being solely tapped by pioneers. It is a viable path towards improving organizational performance.

Melcrum publishing, 2005, opine that Talent Management is more than next new fad, but has become a strategic imperative, for the hr practitioners. 


\section{Research Objectives:-}

a. To study the Significance and benefits of Talent Management Practices

b. To observe \& understand the extent of applications of Talent Management Practices in IT Industries.

\section{Secondary Objectives:}

a. To study the aspects of Talent Management

b. To study the work force challenges faced by IT Companies

c. To study the Talent Definition process

d. To study the process of talent assessment and tracking in the organization

e. To study the process of Career management Practice followed

f. To study the process of succession planning and execution

g. To study the process of retention of critical employees

h. To study the process of Talent Identification

i. To study the process of Talent Identification

j. To study the process of monitoring statutory compliances, diversity, vulnerability, quality of processes quality used and the quality of data about people (validity, reliability, differentiation and usefulness)

k. To study the process Talent Development in the organization.

I. To study the process Talent Development in the organization

m. To study the process Workflow and process control.

$\mathrm{n}$. To study the process of ROI( cost and benefits, effectiveness of Talent Management, improvement in organizational performance, ensuring executive continuity) management practiced.

o. To understand the Role of knowledge management leading to business intelligence , thereby intelligent acquisition of resources

\section{Hypotheses:}

Main Hypothesis of the Study:

Ho: Talent Managementent Practices are practiced in TT industry

Ho: Talent Management Practices are not practiced in 1 i industry 


\section{Sub Hypotheses:}

1. Ho: The work foce Challenges do not exsis in $T$ i industries

Ha: The work force Challenges exist in $T$ industries

2. Ho Roles \& Talent requirements are defined in $T$ industries

Ha: Roles \& talent requirements are not defined in IT industries

3. Ho Talentis acknowiledged in IT industries

Ha: Talentis not acknowiedged in IT industries

4. Ho: Assessing and Tracking Talent process is practiced

Ha: Assessing and Tracking Talent process is not practiced

5. Ho: Talent Acquisition practices are practiced in IT companies

Ha. Talent Acauisition vractices are not practiced in IT combanies

6. Ho: Career Management: is practiced in IT companies

Ha: Career Management: is not nracticed in IT comnanies

7. Ho: Succession Planning: practiced in IT companies

Ha: Succession Planning: not vracticed in IT comoanies

8. Ho: Retention Management: practiced in IT companies

Ha. Retention Management: not nracticed in IT comnanies 
9. Ho: Talent management: practiced in IT companies

$\mathrm{Ha}_{\mathrm{i}}$ Talent management: not practiced in IT companies

10 Ho: Monitoring exposures-ethics, diversity, talent pools vulnerability is practiced in IT $\mathrm{C} 0$.

$\mathrm{Ha}$ : Monitoring exposure-ethics, diversity, talent pools vulnerability is not practiced in IT Co.

11 Ho: Developing Talent: practiced in IT companies

Ha. Developing Talent: not vracticed in IT combanies

12 Ho: Talent Management is tracked in work flow by the managers in IT companies

Ha: Talent Management is not tracked in work flow by the managers in IT combanies

13 Ho: ROI Management is practiced in IT companies

Ha: ROI Management is not practiced in IT companies

\section{Research Methodology:}

This is a basic research study that employs a researcher developed survey. The purpose of this study was used to perform the study aiming to describe the concept and characteristics of Talent management processes in IT Industries, its benefits and hurdles, various factors affecting Talent Management, Talent Management metrics and its linkage with corporate strategy in Large Scale IT companies.

In order to accomplish this, a Survey in Randomly selected IT Companies was chosen so that the impact could be documented quantitatively through questionnaire data. Quantitative data was collected by means of sets of questionnaires utilizing a Likertscale.

The study covers most of the business lines employees including Project \& HR Managers of selected IT companies in Pune.

Population: Large Scale IT Industries in Pune Region

Sampling frame: Software companies in software development, services, applications management etc. 
Sampling Method: Convenience Sampling

Sample Size: 30 large scale IT Companies in Pune Region

\section{Data Analysis and Interpretation:}

The data was calculated and analyzed using graphic table for each question in section one.

The questionnaires were sent to 150 business lines employees including Project Managers and HR Managers of 30 large scale IT Companies in Pune Region.

Table 5.1: Is the breakdown of the respondents

\begin{tabular}{|l|l|l|}
\hline Category of Respondents & No of Respondents & Percentage \\
\hline Project Managers & 50 & $100 \%$ \\
\hline Business line Managers & 50 & $100 \%$ \\
\hline HR Managers & 50 & $100 \%$ \\
\hline
\end{tabular}

The questionnaire includes 28 questions

\section{Table 5.2: The Reliability Table}

\begin{tabular}{|l|l|l|l|l|}
\hline Questions & $\begin{array}{l}\text { Scale Mean if } \\
\text { Question } \\
\text { Deleted }\end{array}$ & $\begin{array}{l}\text { Scale } \\
\text { Variance if } \\
\text { Question } \\
\text { Deleted }\end{array}$ & $\begin{array}{l}\text { Corrected } \\
\text { Question- } \\
\text { Total } \\
\text { Correlation }\end{array}$ & $\begin{array}{l}\text { Alpha if } \\
\text { Question } \\
\text { Deleted }\end{array}$ \\
\hline Q1 & 470.3077 & 5379.3974 & 0.1562 & 0.9702 \\
\hline Q2 & 470.3077 & 5392.5641 & -0.0581 & 0.9703 \\
\hline Q3 & 469 & 5374.6667 & 0.2421 & 0.9702 \\
\hline Q4 & 470.0769 & 5377.2436 & 0.0926 & 0.9703 \\
\hline Q5 & 469.8462 & 5375.4744 & 0.1099 & 0.9703 \\
\hline Q6 & 468.6923 & 5371.7308 & 0.1389 & 0.9702 \\
\hline Q7 & 468.6154 & 5386.7564 & 0.0007 & 0.9705 \\
\hline Q8 & 468.0769 & 5380.9103 & 0.0513 & 0.9703 \\
\hline Q9 & 468.4615 & 5365.9359 & 0.129 & 0.9703 \\
\hline Q10 & 468.5385 & 5365.2692 & 0.1424 & 0.9703 \\
\hline Q11 & 468.4615 & 5394.1026 & -0.0533 & 0.9704 \\
\hline Q12 & 468.9231 & 5357.2436 & 0.2015 & 0.9702 \\
\hline Q13 & 467.8462 & 5385.141 & 0.0393 & 0.9703 \\
\hline
\end{tabular}




\begin{tabular}{|l|l|l|l|l|}
\hline 014 & 467.8462 & 5394.141 & -0.0691 & 0.9704 \\
\hline$Q 15$ & 468 & 5363.8333 & 0.2018 & 0.9702 \\
\hline$Q 16$ & 469.3077 & 5469.0641 & -0.416 & 0.9711 \\
\hline 017 & 469.7692 & 5426.5256 & -0.24 & 0.9707 \\
\hline 018 & 469.6154 & 5424.7564 & -0.1881 & 0.9709 \\
\hline 019 & 469.0769 & 5476.7436 & -0.4251 & 0.9712 \\
\hline$Q 20$ & 468.3077 & 5343.8974 & 0.276 & 0.9702 \\
\hline 021 & 468.6923 & 5289.0641 & 0.6415 & 0.9698 \\
\hline 022 & 468.3846 & 5310.7564 & 0.5173 & 0.9699 \\
\hline 023 & 468.6923 & 5284.2308 & 0.6734 & 0.9697 \\
\hline$Q 24$ & 468.5385 & 5301.7692 & 0.676 & 0.9698 \\
\hline 025 & 468.6154 & 5254.4231 & 0.8109 & 0.9695 \\
\hline 026 & 468 & 5297.1667 & 0.5777 & 0.9698 \\
\hline 027 & 468.1538 & 5247.8077 & 0.7414 & 0.9696 \\
\hline 028 & 468.0769 & 5304.0769 & 0.549 & 0.9699 \\
\hline
\end{tabular}

The reliability of the questionnaire i.e. the Cronbach alpha $=0.9702$

The general rule for Cronbach alpha coefficient is If alpha $>0.9$ it's excellent Hence the Cronbach Alpha \& reliability of the questionnaire is excellent.

Calculation of Confidence Interval:

\section{Parameter1: Work Force Challenges}

There are 5 questions under 'Work Force Challenges'.

\section{Q1-A) Attracting \& Retaining Skilled Professional Workers}

The table of frequency for opinions along with it bar diagram is as below.

\begin{tabular}{|l|l|l|l|l|l|l|}
\hline $\begin{array}{l}\text { Strongly } \\
\text { Disagree }\end{array}$ & Disagree & Neutral & Agree & $\begin{array}{l}\text { Strongly } \\
\text { Agree }\end{array}$ & $\begin{array}{l}\text { Not } \\
\text { Attempted }\end{array}$ & Total \\
\hline 0 & 1 & 2 & 16 & 10 & 1 & 30 \\
\hline
\end{tabular}

The maximum frequency is of opinion 'Agree'.

Here sample proportion,

$\wedge$

$P=16 / 30=0.53, \mathrm{n}=30 \& Z 0.025=1.96$ 
Hence, the $95 \%$ confidence interval for proportion of respondents who are agreeing that there is problem in attracting \& retaining skilled professional workers in the population, is given by

$$
\begin{aligned}
& \left(0.53-1.96 \sqrt{\frac{0.53^{*}(1-0.53)}{30}}, 0.53+1.96 \sqrt{\frac{0.53^{*}(1-0.53)}{30}}\right) \\
& \Rightarrow(0.53-0.1785,0.53+0.1785) \\
& \Rightarrow(0.3515,0.7085) \\
& \Rightarrow(35 \%, 71 \%)
\end{aligned}
$$

\section{Interpretation, Hypotheses Testing}

\section{A Study of Talent Management Practices in IT Industry in Pune Region:}

\begin{tabular}{|c|c|c|c|}
\hline Sr 10 & Parameter & $\begin{array}{l}\text { Hypothesis } \\
\mathrm{H}_{0}\end{array}$ & $\begin{array}{l}\text { Hypothesis } \\
\mathrm{H}_{2}\end{array}$ \\
\hline 1 & Work force Challenges & Rejected & Accepted \\
\hline 2 & $\begin{array}{l}\text { Defining Roles and Talent } \\
\text { Requirement }\end{array}$ & Rejected & Accepted \\
\hline 3 & Defining Talent & Accepted & Rejected \\
\hline 4 & Assessing and tracking Talent & Rejected & Accepted \\
\hline 5 & Talent Acquisition practices & Rejected & Accepted \\
\hline 6 & Career Management & Rejected & Accepted \\
\hline
\end{tabular}

There are 13 parameters which affect Talent Management Practices.

\begin{tabular}{|c|c|c|c|}
\hline 7 & Succession Planning & Rejected & Accepted \\
\hline 8 & Retention & Rejected & Accepted \\
\hline 9 & Talent management & Rejected & Accepted \\
\hline 10 & $\begin{array}{l}\text { Monitoring exposules - ethics, } \\
\text { diversity, Talent Pools } \\
\text { nulmerability }\end{array}$ & Rejected & Accepted \\
\hline 11 & Developing Talent & Rejected & Accepted \\
\hline 12 & Work flow and Process Control & Rejected & Accepted \\
\hline 13 & ROI Management & Rejected & Accepted \\
\hline
\end{tabular}

\section{Hypothesis Testing is done using Population Proportions at $95 \%$ confidence}

\section{Table 6.1: Main Hypotheses Testing}

\section{Main Hypotheses of the Study:}

Ho : Talent Management Practices practiced are in IT industry

Ha: Talent Management Practices not practiced are in IT industry

From the above analysis we can conclude that out of 13 processes of Talent Management identified in this research, 12 are rendered weak. Hence Ha is accepted and Ho rejected. 


\section{Summary of Findings:}

Overall the findings can be summarized on the basis of the above tables that Talent are in Nascent stages, and IT companies are just beginning to warm up to the concept of Talent Management.

\section{Recommendations:}

Based on the results of the survey, the following recommendations are made:

\subsection{Defining Roles \& Talent Requirements}

1. Human Capital should be aligned to Business Strategy

2. There should be consistent Execution and Integration of Talent Programs

3. Competency Mapping should be carried out at Regular Intervals

\subsection{Assessing and Tracking Talent}

1. Talent Reviews should be conducted regularly

2. Leadership Performance Reviews and Development Activities should be a regular activity

3. Succession Planning should be practised

4. Provide meaningful pay differentiation to high performers

\subsection{Talent Acquisition Practices:}

1. The companies should practice effective internal job posting process.

2. The companies should Leverage technology in all aspects of recruitment

3. Competency based recruitment Techniques need to be embraced

\section{Suggested Talent Management Model}

\subsection{Rationale of Model}

The research findings show that Talent Management Practices are less integrated in IT industries and barring Talent Definition all the Processes are weak and need lot of commitment and effort. Hence, the Talent Management proposed on following rationale: 


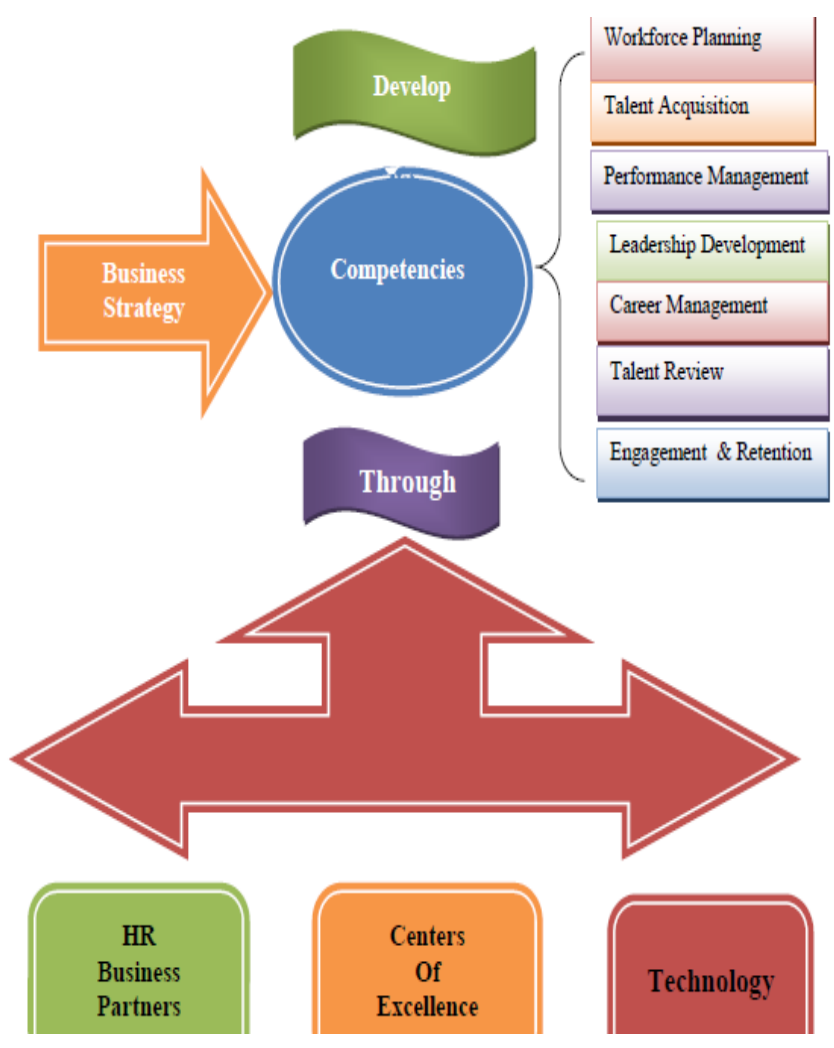

\section{TALENT=COMPETENCE+COMMITMENT+CONTRIBUTION}

\section{Fig 9.1 Template for Talent/Business Strategy Fit}

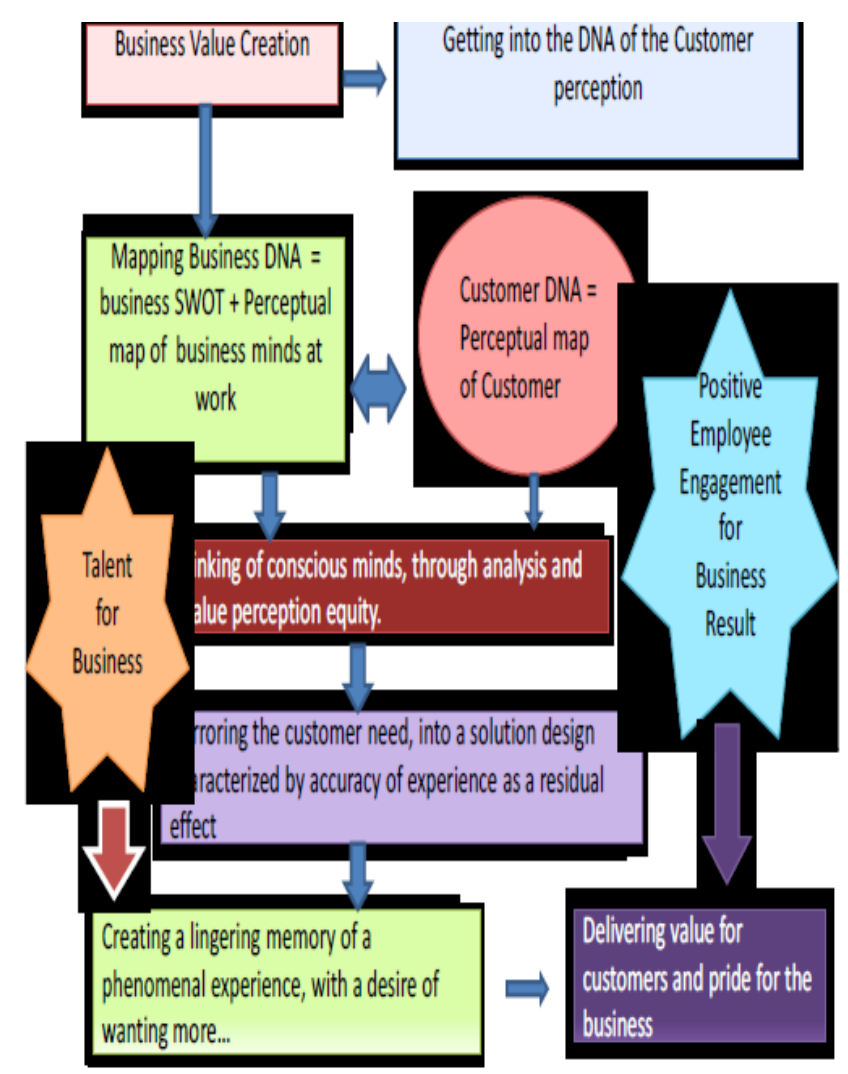

Fig 9.2: The model of business value creation through Talent Management is hence proposed 


\section{Conclusion}

The aim of this research was to gain an insight understanding of how IT organisations approach Talent Management practices. For doing so thirteen Talent Management practices were identified for the study. We need to acknowledge that there are organisations, where there is a need of alignment between the Business, HR and Talent. The findings from this research suggest there are opportunities for organisations to really look at how closely aligned HR, Talent and Business Leaders are in developing Strategic Talent Management Practices, identifying what should be involved, how it is defined and how it should be communicated and implemented in order to develop a "talent mindset".

\section{References}

Talent Management Value Imperatives -Strategies for Successful Execution. The Conference Board, Inc., 32 pages, April 2005 Report by Lynne Morton

Talent Management Raising the Bar, http://dcb9maxnxelio.cloudfront.net/wpcontent/uploads/2012/06/Talent-Management-Raising-the-Bar.pdf

3 Page up People Integrated Talent Management -Optimizing the Employee Life Cycle Whitepaper2http://3y.uu456.com/bp-b935696825c52cc58bd6be4f-2.html

Flexible working: impact and implementation an employer survey, Survey report February 2005, http://www.cipd.co.uk/NR/rdonlyres/257CE4EE-356B-43F5-8927-

5C86203D7AA1/0/flexworksurv0205.pdf

Integrated Talent Management : Optimizing the Employee Life Cycle: http://dcb9maxnxelio.cloudfront.net/wp-content/uploads $\quad$ /2012/06/Integrated-TalentManagement.pdf

"Talent Management - Managing Talent from the danger zone to the value zone," Ernst \& Young, EYGM Limited, 2009. 